\title{
GENRE PECULARITIES OF STEPHEN KING'S NOVELS: HISTORICAL ASPECT
}

\section{Didukh L. I.}

\section{INTRODUCTION}

The horror genre in literature is not one of the most popular, but it is definitely one of the most interesting. The genre is thought to have its beginning not as long ago as other literary genres, although some researchers claim that it was always present in literature. It is worth discussing because fear is human's inseparable and primary emotion, and this is just what horror genre is based on.

Dr Margee Kerr admits that although not everyone likes to feel afraid, there are many people 'who really enjoy the experience, . What is more, she claims that 'there is a strong evidence that this isn't just about personal choice, but our brain chemistry" ${ }^{2}$.

Nevertheless, horror literature is becoming more and more popular nowadays. In this article we discuss when it started, what are the origins of horror and how it was developing through ages. Some of the most popular horror stories are discussed in order to explore the ways of scaring the reader in different times. Although many horror stories had similar plot and characters, it turns out that one author by another was adding some new flavours to it. Slowly the horror genre took the form of horror as we know it today.

However, horror would probably not be the same today without one of its greatest writers - Stephen King. His writing is the topic of the second part of this chapter. He is the one of the most popular writers of the $21^{\text {st }}$ century known all over the world who has revolutionised the horror genre. Even if someone did not read his books yet, probably has heard of him or saw one of the movies based on his novels. Not only has he written many great horror stories, S. King has also written a lot about the poetic peculiarities of the genre. The author shows his readers how he sees horror, what are the readers most afraid of and why they are afraid of it.

\section{The history of the horror genre in modern poetics}

The field of searching for the origins of horror literature is still expanding. Some researchers, like Dr Brandon R. Grafius or Laila Carter,

${ }^{1}$ Ringo, A., 2013. Why Do Some Brains Enjoy Fear? Retrieved March 29, 2019, from www.theatlantic.com.

${ }^{2}$ Ibid. 
claim that reading the Bible and the Greek mythology - texts with fundamental meaning for the European culture - can be a great proof that elements of horror have always been present in literature. Images sated with horror crop up through all literary ages. It is not true to say that in the past there was no horror, that it is an element of the new age. Fear, pain, suffering and death have always been as interesting as beauty and love. Various acts of violence can be found in myths: an eagle feeding on Prometheus's liver every day, Marsyas flayed alive by Apollo, Actaeon tore apart by his own dogs or Ixion bound to a winged fiery wheel that was always spinning. The Bible, especially the Old Testament, also provides many examples of ominous scenes. Some of them could be the murder of Abel, the destruction of Sodom and Gomorrah ${ }^{3}$ or David fighting with Goliath.

Other scholars search for the sources of horror in Marquis de Sade's, Baudelaire's and Lautréamont's works. Many of them are convinced that the horror literature's genesis is strongly associated with the gothic period ${ }^{4}$. According to this group, the first stage of the development of horror literature was the second half of $18^{\text {th }}$ century. It was the time, when gothic fiction started to thrive. As some Western authors claim, the publication considered as the beginning of horror as a writing genre is The Castle of Otranto written in 1764 by Horace Walpole. This novel initiated a very viable for the next fifty years literary current called 'gothic romance'.

At the end of the $18^{\text {th }}$ century, gothic fiction is characterised by some formulaic pattern. The action usually takes place in some old, ruined building with many chambers, dungeons and gloomy corners, which create the atmosphere of terror. Classic elements of the plot are: a beautiful girl in trouble running through dark corridors; a wrongdoer or a villain; a virtuous young man, usually a descendant of the noble family, and a mysterious monk ${ }^{5}$.

However, the end of the $18^{\text {th }}$ century was also the time of Marquis de Sade mentioned earlier. According to Michał Kruszelnicki, nobody ever managed to excel de Sade in terms of the scale of unleashing the perverse and harsh imagination ${ }^{6}$. His works were full of erotic, but also violent and blasphemous scenes. In fact, his name is the root for words sadism and sadist. Sade spent nearly half of his life in various prisons, where many of his works

${ }^{3}$ Kruszelnicki, M., 2010. Oblicza strachu: Tradycja i wspótczesność horroru literackiego. Toruń, Wydawnictwo Adam Marszałek. P. 24-26.

${ }^{4}$ Ibid. P. 19.

${ }^{5}$ Borowiec, P., 2016. Transylwania nad Tamiza: Londyn w klasycznej literaturze grozy część 1. [in:] OkoLica Strachu no. 1(1). P. 96-98.

${ }^{6}$ Kruszelnicki, M., 2010. Oblicza strachu: Tradycja i współczesność horroru literackiego. Toruń, Wydawnictwo Adam Marszałek. P. 28. 
were written. Even though he was widely criticised, his fiction of sadism was closely bounded with the Gothic novel and surely had some impact on it.

As the gothic romance started to peter out, one more remarkable novel was released. Frankenstein; or, The Modern Prometheus written by Mary Shelley in 1818 is considered to be the first science fiction creation. It is a gothic story fraught with philosophical and intellectual content, as well as with pessimism. Frankenstein revolutionised the genre. There are no old ruins, no monks. Instead, an important motive which is present until today is The Crazy Scientist and the foul monster he has created.

While M. Shelley was still an active writer, a short story entitled The Man of the Crowd was released. It was year 1840 and the author was Edgar Allan Poe - an American writer well known for his tales of mystery and the macabre. In this story London is presented as a gothic maze space. The narrator is an unknown person following an old man through London. While he is observing the city, he generalises crowds of people, describes them like a wild animal observer and tries to find out whether the old man has committed a felony. E. A. Poe's short novella was path breaking and innovative at that time. Indeed, it initiated a stream in horror literature called 'urban gothic'. Since then, most gothic and horror stories took place in London - the centre of civilisation and culture.

In 1885 British public opinion was shattered after William Thomas Stead published a series of articles entitled The Maiden Tribute of Modern Babylon. Articles broached the topic of child prostitution and sensitised the society to an important literary motif: child's detriment. The motif was used at the very beginning of one of the most popular novels written by R. L. Stevenson Strange Case of Dr Jekyll and Mr Hyde: 'I was coming home from some place at the end of the world, about three o' clock of a black winter morning, and my way lay through a part of town where there was literally nothing to be seen but lamps. Street after street, and all the folks asleep - street after street, all lighted up as if for a procession and all as empty as a church - till at last I got into that state of mind when a man listens and listens and begins to long for the sight of a policeman. All at once, I saw two figures: one a little man who was stumping along eastward at a good walk, and the other a girl of maybe eight or ten who was running as hard as she was able down a cross street. Well, sir, the two ran into one another naturally enough at the corner; and then came the horrible part of the thing; for the man trampled calmly over the, child's body and left her screaming on the ground, ${ }^{7}$. Injured girl must have caught the reader's attention from the first moment. Yet, the author also used the element of gas

\footnotetext{
${ }^{7}$ Stevenson, R.L., 2012. The Strange Case of Dr. Jekyll and Mr. Hyde. Simon \& Brown.
} P. 3-4. 
'lamps', which are a natural and apparent component of the 'urban-gothic' scenery. This motif of gas lamps is used twice more in this novel - as an element of fear and a distinctive symbol of London. Dr Jekyll and Mr Hyde frightened R. L. Stevenson's wife so badly, that the author decided to burn the manuscript in the fireplace, but he wrote it once again during the next three days $^{8}$. This shows that the story was incredibly terrifying, but also extremely gripping. What is more, Mr Hyde is a murderer, so the novella also anticipated another English outrageous case: murders in Whitechapel.

Jack the Ripper could have been an afflation for some horror stories. A serial killer who is believed to have murdered at least five women is mentioned for example in The Great God Pan, a horror novella by Arthur Machen. The difference between Jack the Ripper and Helen - the main heroine of the novella - is the district of committing murders. While Jack the Ripper was killing on the East End, Helen was a creature who seduced her victims on the West End. She was more than just a murderer - a fruit of the demonic relationship of a woman and an ancient deity. Such a creature was derived straight from the Gothic tradition. She was a femme fatale, a demon completely inconsistent with the accepted model of a woman in London. Helen brought her deviation and her predatory erotic life into the most elite part of the English capital, and that was the reason why so many British readers were shocked reading The Great God $\mathrm{Pan}^{9}$.

Romantic era was also an important period for literature with elements of horror. According to Maria Janion, romanticism has created new theories of imagination. It was the first literary movement in the modern culture that on such a scale released dreams, fantasies and phantasms in a way that was not generally known to the foregoing art ${ }^{10}$. It seems that Romantics' works allowed human's cherishing of terror to evince itself in literature. Entire modern fantasy, including horror, derives great number of motifs, characters and props from romanticism ${ }^{11}$. One of the romantic authors and concurrently one of the most important horror authors was E. A. Poe, mentioned above. His works, as well as Nathaniel Hawthorne's works were based on occult or supernatural psychology. Other romantic writers believed that imagination and the sublime, that refers to some extraordinary experiences, are some of the most important elements of literature.

\footnotetext{
${ }^{8}$ King, S., 1995. Danse Macabre. Warszawa, Prószyński i S-ka. P. 81.

${ }^{9}$ Borowiec, P., 2016. Transylwania nad Tamiza: Londyn w klasycznej literaturze grozy część 1.[in:] OkoLica Strachu no. 1(1), P. 104-105.

${ }^{10}$ Janion, M., 2001. Prace wybrane, t. 3: Zło i fantazmaty. Kraków, Universitas. P. 158.

${ }^{11}$ Kruszelnicki, M., 2010. Oblicza strachu: Tradycja $i$ współczesność horroru literackiego. Toruń, Wydawnictwo Adam Marszałek. P. 30.
} 
Although horror as a literary genre in no way existed before the $20^{\text {th }}$ century (gothic literature in the $18^{\text {th }}$ century and phrenetic literature in the beginning of the $19^{\text {th }}$ century), it has always existed and will exist in the human subconsciousness. It was not born in some determined period or type of a novel. Great works of Homer, Shakespeare, Baudelaire or Greek drama writers were not written to be typical horrors. Neither was the Bible or the mythology. However, in these works many elements of consciously applied terror were present and they are now used or followed by modern horror writers. In conclusion, it seems to be true to say that horror literature is as old as the fear itself ${ }^{12}$.

\section{Genre peculiarities of Stephen King's writing style}

Stephen King is known for his mastery in the field of the modern horror. It is an indisputable and unargued fact ${ }^{13}$. Although horror is not the only genre he works in, this is the one he loves the most. King states: 'The best tales in the genre make one point over and over again - that the rational world both within us and without us is small, that our understanding is smaller yet, and that much of the universe in which we exist is, so far as we are able to tell, chaotic. So the horror story makes us appreciate our own well-lighted corner of that chaotic universe, and perhaps allows a moment of warm and grateful wonder that we should be allowed to exist in that fragile space of light at all ${ }^{14}$. Probably writing horror stories is for the author a way of escaping from reality and to look at his life in a broader perspective. He wishes that reading them would be the same for his readers.

As a child, S. King used to go to the cinema to see horror movies, even if his mother was not happy about it. He also loved to read a lot of horror or fantasy stories. This is why a strong influence of writers such as E. A. Poe, R. Matheson or H. P. Lovecraft on S. King's works can be noticed. He admits: 'I had read Poe and I had read a lot of Gothic novelists, and even with Lovecraft I felt as though I were in Europe somewhere. I knew instinctively that I was trying to find a way to get back home, to where I belonged. And then I read Richard Matheson's I Am Legend ... And I realised then that horror didn't have to happen in a haunted castle; it could happen in the suburbs, on your street, maybe right next door' ${ }^{15}$. This short fragment of an interview

${ }^{12}$ Kruszelnicki, M., 2010. Oblicza strachu: Tradycja i współczesność horroru literackiego. Toruń, Wydawnictwo Adam Marszałek. P. 33.

${ }^{13}$ Ibid. P. 150.

${ }^{14}$ King, S., 1981. Introduction, [in:] Pronzini B., Malzberg B. \& Greenberg M.H. The Arbor House Treasury of Horror and the Supernatural. New York, Arbor House. P. 18.

${ }^{15}$ Winter, D. E., 1989. The Art. Of Darkness: The Life and Fiction of the Master of the Macabre: Stephen King. London, Hodder \& Stoughton. P. 21. 
shows that although S. King was inspired by other writers, he tried to find his own way to write, his 'brand mark'. He wanted his horror to be different than most gothic stories, to be more realistic and closer to his readers. This goal has been achieved, and in fact, his name did become a brand.

King claims, that the horror genre 'is one of the most delicate known to man, and it must be handled with great care and more than a little love ${ }^{16}$. His love for the horror literature is apparent. The rate at which he releases new novels is a great proof that writing horror stories is not only his way of earning money - this is his true passion. One of the novels written by him - It - shows that King is a real master of horror stories. Many people are convinced that this is his best work. It takes the reader back to his childhood memories, when sensations were clear and acute, when the line between psyche and the real life was very thin. King describes feelings and experiences of children as if he was a child at the moment. His characters, although very young, need to face powerful forces - the Good and the Evil. The author uses many motifs that are not supernatural, e.g. a clown or the domestic abuse, but also allows It become what his characters fear the most, e.g. a werewolf. Nonetheless, he uses all of them in the best way to scare the reader, because this is what he is good at scaring to death.

S. King has also divided the horror genre into three levels: 1) the level of pure terror, which is full of 'thrilling stories' that are scary only because of what our imagination can see in them; 2) the level of fear, which is the level of stories which show us what physically already causes us to feel scared; 3) the level of execrableness, where literature is full of descriptions evoking disgust and revulsion ${ }^{17}$. Emotions such as fear, disgust, revulsion, which horror literature is supposed to produce in readers, are rather negative, yet paradoxically soughtafter $^{18}$, otherwise horror would not have so many supporters.

There is one basic assumption that makes a story become a horror - it needs to be based on fear that is common to all people. One can think of a huge number of things that people can be afraid of. Some of them are common for most of the mankind, e.g. fear of dangerous animals or uncontrolled fire. Others are specific to some groups of people, like the fear of a monster under the bed that makes children all over the world afraid. However, some horror writers or those, who want to become horror writers, wonder if there are some things that can scare anyone. S. King gives his own 'top ten' of the scariest topics to write about:

${ }^{16}$ King, S., 1986. The Horror Writer and The Ten Bears. [in:] Miller C. \& Underwood T. (ed.), Kingdom of Fear: The World of Stephen King (p. 12). Falmouth, Hodder \& Stoughton.

${ }^{17}$ King, S., 1995. Danse Macabre. Warszawa, Prószyński i S-ka. P. 44.

${ }^{18}$ Kruszelnicki, M., 2010. Oblicza strachu: Tradycja i współczesność horroru literackiego. Toruń, Wydawnictwo Adam Marszałek. P. 23. 
1. 'Fear of the dark;

2. Fear of squishy things;

3. Fear of deformity;

4. Fear of snakes;

5. Fear of rats;

6. Fear of closed-in places;

7. Fear of insects (especially spiders, flies, beetles);

8. Fear of death;

9. Fear of others (paranoia);

10. Fear for someone else ${ }^{19}$.

King calls these fears 'bears' and combines them to create different stories. As an example, when the author took fear \#1 and \#10, he wrote a story called The Boogeyman. What can be surprising for some readers or writers, there are no vampires or werewolves on the list, even though they can be found in some of S. King's works.

Apparently, the most popular horror writer prefers to reference to the most essential human fears - the real ones, which can be found in our everyday life. A perfect example of S. King's novel which tells a terrifying story about something common is Cujo, where 'most of the terror comes from something that is quite natural: a wonderfully loving and friendly St Bernard dog ${ }^{20}$. When the dog becomes rabid and starts killing people, the story turns into a real horror seasoned with some spicy threads relevant to the novel's characters. The plot is so terrifying to the reader, because anyone can meet a rabid dog one day. What S. King is trying to do is to awaken the receiver's imagination which will certainly evoke fear.

According to Whitley Strieber 'part of good horror is the it's not happening to me syndrome. I am here, in this bedroom, reading all of these fascinating misfortunes, and they are more horrible than the fact that the dog left his calling card in one of my good shoes again this morning. These deaths are lingering agonies far worse than anything I need expect, even if I go down in a jet and burn to death amid a jumble of agonised fellow-passengers ${ }^{21}$. The conclusion is: people like to read horrible stories as long as they are safe. People like to read about others' terrible experiences, because the worst experience that they could have is not even half this awful. S. King knows

${ }^{19}$ King, S., 1986. The Horror Writer and The Ten Bears. [in:] Miller C. \& Underwood T. (ed.), Kingdom of Fear: The World of Stephen King (p. 10). Falmouth, Hodder \& Stoughton.

${ }^{20}$ Greeley, A. M., 1986. Stephen King's Horror Has a Healing Power. [in:] Miller C. \& Underwood T. (ed.), Kingdom of Fear: The World of Stephen King (p. 19). Falmouth, Hodder \& Stoughton.

${ }^{21}$ Strieber, W., 1986. Thanks to The Crypt-Keeper. [in:] Miller C. \& Underwood T. (ed.), Kingdom of Fear: The World of Stephen King (p. 42). Falmouth, Hodder \& Stoughton. 
human brain well enough to know what terrifies us most. He is guiding his readers through all the ominous events he had fancied and makes them feel thrilled, but they know that after closing the book they will be safe in the world they know.

W. Strieber continues: 'I am here, safe in this bedroom. Maybe something awful is going on outside that window. Maybe a psychotic is climbing up the house with a meathook in his hand. But, even if that's true, what he's going to do to me will not hurt as much as what Jack Torrance is going to do to his wife with that axe, because Jack is so slow and the psycho will have to be quick to catch me. We are all running, always, from real fears.

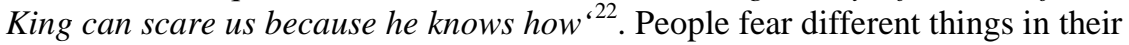
everyday life, so they want to escape from that and read about somebody else's fears. S. King and other horror writers take advantage of this fact and do their best to think of the most terrifying things in the world. Nevertheless, King is the master of this art. He wrote: 'I recognize terror as the finest emotion. So I try to terrorize the reader ... But if I find I cannot terrify, I will try to horrify. And if I cannot horrify, I'll go for the gross-out. I'm not proud,23. This is why S. King's writing style is not always literarily correct or commonly cromulent. His main goal is to evoke fear in his readers, not to be perfectly neat.

S. King's first released novel was a huge success and a huge shock both to him and to his readers. It was nothing like popular literature in America at that time, yet, people loved it. Although S. King has written many stories before, Carrie was the one that gave him success. It is probably the most eccentric novel written by him, but it showed the real talent of the author the ability to bewilder and terrify the reader.

According to Chuck Miller, a Californian based publisher and editor, 'Carrie is Stephen King's miracle,24. Probably, S. King would agree. His life before Carrie was not always easy. Miller continues: 'King and his family lived a hand-to-mouth existence in rural Maine. Teaching high school English classes by day and writing fiction at night, he lived with his wife and three small children in a rented trailer. A few of his stories had seen print but he had authored four unsold novels and he despaired of the life of a frustrated, unpublishable writer. Carrie, his fifth novel, was salvaged from the waste basket by his wife, Tabitha, who persuaded King to finish the aborted short story about a troubled adolescent girl with telekinetic powers. It soon became a full-length

${ }^{22}$ Strieber, W., 1986. Thanks to The Crypt-Keeper. [in:] Miller C. \& Underwood T. (ed.), Kingdom of Fear: The World of Stephen King (p. 42). Falmouth, Hodder \& Stoughton.

${ }^{23}$ King, S., 1995. Danse Macabre. Warszawa, Prószyński i S-ka. P. 37.

${ }^{24}$ Miller, C., 1986. Stephen King Goes to the Movies. [in:] Miller C. \& Underwood T. (ed.), Kingdom of Fear: The World of Stephen King (p. 167). Falmouth, Hodder \& Stoughton. ISBN 0-450-41021-8. 


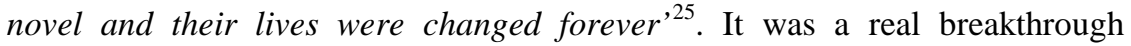
in King's career and it was completely well-earned, because Carrie really is special.

The most important element of the horror genre is the theme of the story. Without a good theme it is impossible to write a good horror novel. Horror genre is usually associated with themes like vampires, ghosts and other supernatural creatures. Carrie does not involve any of these themes and still remains a very popular horror story. As the title suggests, the main theme of this novel is Carrie herself - her unguessed possibilities and supernatural power that becomes apparent as the action develops, but also her relations with mother and peers. All of these elements mixed give readers a perfect theme for an unusual horror story.

The next thing that is an important genre element of Carrie is setting. Usually horror stories are set in a haunted house, an old castle or an abandoned building. However, S. King always tries to set his plot in the modern world which is well known to the reader. This is why the narrative of Carrie starts in the school bathroom - definitely not a typically terrifying place. From the newspaper note on the beginning of the book the reader can find out that Carrie lived in Chamberlain, a small town in Maine. Maine is where the author comes from and where he still lives, so most of his novels are set in that state. The biggest part of the plot takes place in Carrie's house and at her school, but the events involve all the habitancy of Chamberlain.

Another element worth considering is characters. Story's protagonists are very interesting. Carrie is a story about a teenage girl who is awkward, lonely and, simultaneously, powerful. She is presented in a way that allows every reader to imagine what she looked like. 'A toad among the swans ... She looked typically like a scapegoat, a permanent target of tricks, object of class ridicule, always duped, fooled and humiliated ${ }^{26}$ [translation mine]. Definitely, Carrie was not a dull character, and neither was her mother, a religious fanatic with very strong personality. The narrator describes her as a very tall woman with blue eyes and frameless glasses, who always had a Bible in her leather bag. 'Mother was the priest, Carrie was the congregation, ${ }^{27}$ [translation mine]. Relations between Carrie and her mother are very tense. There are no feelings that should be occurring in a normal mother-daughter relationship. Margaret White was convinced that Carrie was the fruit of sin. Physical and mental abuse was her strategy to bring her

${ }^{25}$ Miller, C., 1986. Stephen King Goes to the Movies. [in:] Miller C. \& Underwood T. (ed.), Kingdom of Fear: The World of Stephen King (p. 167). Falmouth, Hodder \& Stoughton. ISBN 0-450-41021-8.

${ }^{26}$ King, S., 2013. Carrie, trans. D. Górska. Warsaw, Prószyński i S-ka. P. 10.

${ }^{27}$ King, S., 2013. Carrie, trans. D. Górska. Warsaw, Prószyński i S-ka. P. 49. 
daughter up in holiness. However, not only Carrie and her mother are interesting characters of the novel. There are also protagonists such as Sue Snell or her boyfriend, Tommy Ross, who played a major role in what happened later in the story. S. King's way of presenting characters will be discussed in detail in the second chapter of the paper, but creating such variegated protagonists is definitely his identification mark, for characters are an extremely important element of the horror genre.

The narrative structure of the novel is also different from other works in the horror genre. It is in a big part epistolary: 'only about half of the novel is written in a traditional narrative style, with the remainder presented in bogus items of documentation: newspaper clippings, letters, excerpts from books, transcripts of legislative hearings, teletype news reports ${ }^{28}$. What is interesting about this method is the fact, that these fragments from other sources are not put in another chapter or part of the book, they are inwrought in the middle of the narrative. This is rather unprecedented in the horror genre, rather often occurring in documentary or historical books. All of these intentional measures make the reader feel a part of the plot. It also evokes reader's curiosity and stimulates emotions. What is more, S. King puts his characters' thoughts in brackets what is a great way of turning up the speed of the narration and engaging the reader in the action: 'Thank you (I'm not afraid) mom. . . Carrie was trying to swallow the ball that got stuck in her throat, and it (I'm not afraid oh yes yes I am afraid) was only partly possible (translation mine) ${ }^{29}$. All of these written 'thoughts' allow to notice the psychological side of Carrie's identity - her unpredictability, her ferociousness, but also the motives of her actions. It is not common in horrors to use such narration, but it cannot be denied that it makes Carrie something special, that every horror lover should read at least once in his life.

There are two extremely important moments of the book. Apart from the climax, which is usually the greatest part of the novel, the beginning and the end are crucial. The beginning of the story is the moment when the reader might become completely engrossed or get bored and leave the book behind. The end is definitive - the reader will remember the book as a fascinating story and recommend it to everyone, or feel disappointed and be left with tattered impression of the book. In Carrie S. King took care of both of these elements. 'The story begins and ends in blood. When Carrie is drenched in pig's blood on the stage, the surprised promgoers laugh like unforgiving children. In response, like a dark, avenging angel, Carrie wields her hidden powers with devastating telekinetic force, indiscriminately destroying the people and buildings around

${ }^{28}$ Winter, D. E., 1989. The Art. Of Darkness: The Life and Fiction of the Master of the Macabre: Stephen King. London, Hodder \& Stoughton. P. 33.

${ }^{29}$ King, S., 2013. Carrie, trans. D. Górska. Warsaw, Prószyński i S-ka. P. 82-83. 
her ${ }^{30}$. Such an ending cannot remain unsung. Every reader remembers that the end of Carrie was spectacular, and the rising action was so intriguing that it was not possible to close the book at the moment. Among other elements, this is what made King's first published book a great success and the beginning of a wonderful writing career.

The theme of another King's successful novel is a bit different than it was in Carrie, yet it still has many similar elements. The Shining is a story based on the place where the characters reside, but it also involves some supernatural abilities as it was in Carrie. Some important motifs that also contribute to the main theme are: family problems, writing, memories from the past and isolation. The theme of an empty, big building was quite popular in the horror genre in the past and S. King decided to use it this time, yet in a bit different role.

The Shining's setting is crucial for the plot. The place of the action is an empty hotel cut off from the rest of the world. It is also a reference to S. King's life. 'In late September of 1974, Tabby and I spent a night at a grand old hotel in Estes Park, the Stanley. We were the only guests as it turned out; the following day they were going to close the place down for the winter. Wandering through its corridors, I thought that it seemed to be the perfect maybe the archetypical - setting for a ghost story, ${ }^{31}$. During a dream, S. King thought of a story that became The Shining. 'The Overlook Hotel stands high in the Rocky Mountains, forty miles from the nearest town over roads that are impassable through six months of bitter winter. This great, isolated house, with its dignified architecture and accumulation of history, created the suggestion of a settled order ... And like its Gothic predecessors, the Overlook symbolizes the pride and guilt of authentic tragedy ${ }^{32}$. In a big, empty hotel without the ability to get away, anything can happen. The setting is indeed perfect for the horror story. However, it was not a normal building. 'This inhuman place makes human monsters ${ }^{, 33}$ the novel says. The characters started to suspect it too. Probably the first time Jack Torrance started thinking that there is something wrong was when the wasps attacked his son, Danny. 'Suddenly, Jack thought that he did not like the Overlook anymore, that it looks like his son was not attacked by the wasps, somehow extant after bombing, but the hotel itself ${ }^{34}$

${ }^{30}$ Miller, C., 1986. Stephen King Goes to the Movies. [in:] Miller C. \& Underwood T. (ed.), Kingdom of Fear: The World of Stephen King (p. 170). Falmouth, Hodder \& Stoughton.

${ }^{31}$ Winter, D. E., 1989. The Art. Of Darkness: The Life and Fiction of the Master of the Macabre: Stephen King. London, Hodder \& Stoughton. P. 54.

${ }^{32}$ Ibid. P. 54-55.

${ }^{33}$ Ibid. P. 55.

${ }^{34}$ King, S., 1998. The Shining. Warsaw, Prószyński i S-ka. P. 160. 
[translation mine]. This was just the beginning, but it shows how important element of the story a setting can be.

Characters of The Shining are also extremely interesting and important for the action. The family of Torrances had quite a rough history behind, and the reader discovers it while the action is rising. Jack Torrance, a head of the family, is a teacher who lost his job, so he decides to focus on writing. He also believes that moths spent at the Overlook Hotel as a caretaker will help him achieve success in writing. As the story develops, Jack is slowly turning from the protagonist to the novel's main antagonist. His character is presented in a very interesting way. The reader can imagine how loving and familyminded he is, which seems apparent from the dialogues with his wife and son. However, as the narrator reveals the history of the family, acts of abuse and problems with alcohol, the perception of Jack Torrance in reader's mind changes. One of the most terrifying moments in the family's history is described already in the third chapter of The Shining: 'When he walked back to his home office and saw Danny, standing there with a smile only in tracksuit pants, a red cloud of rage gradually outblazed his reasoning ability ... Danny started talking and that was the very moment when Jack grabbed and wrenched his son's arm, in order to force him to relinquish the typewriter rubber and an automatic pencil from his tight fingers. Danny screamed quietly... no... no... tell the truth, he yelled ... He turned Danny around to give him a slap, sticking his adult fingers into a thin layer of body on the boy's forearm, clenching his fist. The crack of a breaking arm was not loud, but very resonant, FORCEFUL, but not loud ${ }^{35}$ [translation mine]. Although at that moment his wife, Wendy, truly hated Jack, the family managed to work it over with time. Wendy was a very good mother and tried to be a very good wife, but subsequently started to view her husband as a threat. She can be

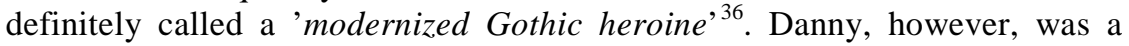
special child. 'He is gifted (or cursed) with powerful telepathic and psychic abilities that enable him to communicate with the evil spirits present in the Overlook Hotel ${ }^{37}$. He also has an imaginary friend, Tony, who can have a big impact on Danny's life and actions. One more important character of The Shining is Dick Halloran, an adult with the same abilities as Danny's who plays a major role at the ending of the story. All of these characters, although they are modern, have some features present in the gothic horror stories.

The reader is also allowed to look into the characters' minds due to the narrative which is similar to the one used in Carrie. The Shining is another

${ }^{35}$ King, S., 1998. The Shining. Warsaw, Prószyński i S-ka. P. 24-25.

${ }^{36}$ Winter, D. E., 1989. The Art. Of Darkness: The Life and Fiction of the Master of the Macabre: Stephen King. London, Hodder \& Stoughton. P. 57.

${ }^{37}$ Retrieved April 1, 2019, from www.gradesaver.com. 
novel in which S. King used his system of describing characters' thoughts. This time we can mainly read little boy's thoughts: 'Danny's lips shivered. He is going to start crying. What if he cannot stop? (I will not cry, I will not cry, no, no, I won't)' [translation mine] ${ }^{38}$. Although in The Shining the narrator does use some punctuation marks, Danny's thoughts are written in brackets, just like Carrie's. Jack's and Wendy's mind is also an open space for the recipient of the novel, for Danny can read their thoughts. This measure often taken by S. King is supposed to make the reader even more involved in the plot.

The Shining also begins in an interesting way and the action is slowly rising until the terrifying climax by the end of the novel. The book is definitely longer than Carrie, so many more detailed descriptions can be found in it, but the plot does not become tiring at any moment. The narrative is often interrupted with memories from the past which give the reader lots of important information. The climax is basically also the ending of the story, so the novel is very memorable, although the reader needs to wait for the distillation of the horror quite long.

Some readers claim that S. King's best horror story is It. The theme of this novel similarly involves children. This time, however, there is a supernatural creature occurring. Although it looks nothing like a typical horror monster, but just a clown living in the drains, it has the ability to become the child's biggest fear, and this is the novel's main theme. There are also other extremely important motifs in the novel: childhood, friendship, the power of belief and the unity that is the source of strength and courage.

The setting of It is a common setting used by S. King - a fictional town in Maine. This time the town's name is Derry and the author devised it inspired by the town he lives in - Bangor, Maine ${ }^{39}$. The town is a place where many people live, but most of them are not aware that they are not alone. Derry's canals are inhabited by some ancient creature that wakes up every 27-30 years, and the creature, as in the title, is called It.

The novel has even more interesting characters that the previous novels discussed. Although the main antagonist, It, is probably the most fascinating, there is also a group of children that, apart from the monster, are the most important elements of the plot. They form 'the Loser's Club' and the leader of it is Bill Denbrough, a teenage boy whose little brother got killed by It. Although he had a tendency to stutter, he was respected by the rest of the group. Bill was the most determined to defeat the creature that took his brother, George. One of Bill's best friends was Richie Tozier, a boy with thick glasses and a foul mouth. Eddie Kaspbrak was also one of the 'losers'. He is described as the shortest of

\footnotetext{
${ }^{38}$ King, S., 1998. The Shining. Warsaw, Prószyński i S-ka. P. 338.

${ }^{39}$ Truffaut-Wong, O., 2017. Derry, Maine, Isn't a Real Town But You Can Still Visit at Your Own Risk. Retrieved April 1, 2019, from www.bustle.com.
} 
them and, for most of the story, the most afraid of getting sick or injured. Mike Hanlon was the boy who last joined the club. He was the only dark-skinned person in the group and he was persecuted by one of the school boys, Henry Bowers. Stan Uris, on the other hand, was the only Jewish kid at school. He was really mature for an 11-year old, but also the most afraid of It. The smartest member of the group was Ben Hanscom, although he was obese and usually neglected at school. The only girl in the club was Beverly Marsh. She was a pretty girl who fancied Bill, she was also very brave and loyal, although some other teenagers thought she was permissive, which was not true. She also had a difficult situation at home. Her relationship with father is similar to relations between Jack Torrance and Danny from The Shining. Beverly's father always said he was worried about her, but the reader can conclude that she was afraid of him. Probably, the motif of abuse appears in this novel as well as in many others. All of these 7 young characters are not very powerful separately, but together they form a strong group that can face every danger. The novel would not be the same without them, for they are the essential part of the plot and the biggest opponent of It.

The narrative is one more connection between It and novels such as Carrie and The Shining. Once again the author uses a method of describing character's thoughts: 'What if he went to get Eddie's stuff and came back to find Eddie unconscious? Unconscious or (don't shit please don't think that) or even dead, his mind insisted implacably. (like Georgie dead like Georgie) ${ }^{40}$. Although such interjections are not as common as in Carrie, they are written in the same way: in brackets, with no punctuation marks, no big letters. It is an identification mark of S. King's writing style. This is how he makes the reader walk in the characters' shoes. When we read their thoughts, we know exactly how they feel, whether they are scared or excited. It allows us to understand their human feelings and to actually feel them on our skin, what makes us even more involved in reading the story. We cannot stop, for the story is already turning like a fast big wheel and we do not want to get out.

The plot structure of $I t$ is immensely interesting. The novel is divided into five parts, and each of them is followed by an interlude that concerns Derry. The first part, entitled 'The Shadow Before' consists of 3 chapters relating to the past. The second one, 'June of 1958', is focused on the actual events connected with the Loser's Club, so it can be called the present part. The next section, 'Grownups', as the title suggests takes the reader to the future - the time, when the 7 kids are adults already and each of them has his or her own life. In the fourth part entitled 'July of 1958' it is easy to notice that the

\footnotetext{
${ }^{40}$ King, S., 2011. It. London, Hodder \& Stoughton. P. 271.
} 
plot turns back to the present and is strongly connected with the second part. The last part concerns 'The Ritual of Chüd', which was a kind of a psychic battle in which adult protagonists destroy $\mathrm{It}^{41}$. All of this interspersed with fragments of Mike Hanlon's book about the history of Derry can make the reader confused. The past, the present and the future are mixed not only between different parts of the book, but even within single chapters. All of this makes it difficult to find the climax of the whole story. Actually, each part of the novel has its own climax. This is not a typical solution and can be considered as a novelty in the field of horror genre.

\section{CONCLUSIONS}

Horror literature is becoming more and more popular nowadays having its genre and poetic peculiarities. In this article we discuss when it started, what are the origins of horror and how it was developing through ages. Some of the most popular horror stories had been analysed in order to explore the ways of scaring the reader at different stages of its development.

S. King's works have made a prominent change to the horror genre. His specific way of writing has left a permanent sign on literature. It was not an easy thing to do, for horror is not a very original genre.

Thus, the main features of S. King's writing style are: the usage of child or teenage characters, basing on common human fears and terrorizing readers with describing outwardly normal situations in a way that gives the shivers. The writing style of the author will be discussed more extensively in the further part of the research.

\section{SUMMARY}

The article deals with S. King's genre peculiarities, writing methods, specific measures. Examples of three novels written by the master of modern horror show the peculiarities of his talent. They allow to notice S. King's different approach to the horror genre, even though some critics do not approve his style. All of these novels described above have similar plot structure elements. The climax in most of these stories is moved to the last part of the plot, so the action is rising for the most part of the story. The genre of novels can be certainly defined as horror with lots of psychological elements. The narrative in novels Carrie and It is very similar: it changes from one character to another, switches between the past and present. These narrative elements can be also noticed in The Shining and many other novels written by S. King. Moreover, in many of these novels some specific elements of narration occur: particularly, characters' thoughts are written in brackets. This measure is

\footnotetext{
${ }^{41}$ King, S., 2011. It. London, Hodder \& Stoughton. P. 271.
} 
an important and very specific feature of S. King's novels, because it gives readers additional information about emotions that are involved in the story, and it is not a commonly used way of writing.

The article also mentioned the author's personal view on horror as a literary genre and his idea of things that scare the readers.

\section{REFERENCES}

1. Borowiec, P., 2016. Transylwania nad Tamiza: Londyn w klasycznej literaturze grozy - część 1. [in:] OkoLica Strachu no. 1 (1).

2. Greeley, A. M., 1986. Stephen King's Horror Has a Healing Power. [in:] Miller C. \& Underwood T. (ed.), Kingdom of Fear: The World of Stephen King. Falmouth, Hodder \& Stoughton.

3. Janion, M., 2001. Prace wybrane, t. 3: Zło i fantazmaty. Kraków, Universitas.

4. King, S., 1981. Introduction, [in:] Pronzini B., Malzberg B. \& Greenberg M.H., The Arbor House Treasury of Horror and the Supernatural. New York, Arbor House.

5. King, S., 1986. The Horror Writer and The Ten Bears. [in:] Miller C. \& Underwood T. (ed.), Kingdom of Fear: The World of Stephen King. Falmouth, Hodder \& Stoughton.

6. King, S., 1995. Danse Macabre. Warszawa, Prószyński i S-ka.

7. King, S., 1998. The Shining. Warsaw, Prószyński i S-ka.

8. King, S., 2011. It. London, Hodder \& Stoughton.

9. King, S., 2013. Carrie, trans. D. Górska. Warsaw, Prószyński i S-ka.

10. Kruszelnicki, M., 2010. Oblicza strachu: Tradycja i współczesność horroru literackiego. Toruń, Wydawnictwo Adam Marszałek.

11. Miller, C., 1986. Stephen King Goes to the Movies. [in:] Miller C. \& Underwood T. (ed.), Kingdom of Fear: The World of Stephen King. Falmouth, Hodder \& Stoughton. ISBN 0-450-41021-8.

12. Retrieved April 1, 2019, from www.gradesaver.com.

13. Ringo, A., 2013. Why Do Some Brains Enjoy Fear? Retrieved March 29, 2019, from www.theatlantic.com.

14. Stevenson, R.L., 2012. The Strange Case of Dr. Jekyll and Mr. Hyde. Simon \& Brown.

15. Strieber, W., 1986. Thanks to The Crypt-Keeper. [in:] Miller C. \& Underwood T. (ed.), Kingdom of Fear: The World of Stephen King. Falmouth, Hodder \& Stoughton.

16. Truffaut-Wong, O., 2017. Derry, Maine, Isn't a Real Town But You Can Still Visit at Your Own Risk. Retrieved April 1, 2019, from www.bustle.com. 
17. Winter, D. E., 1989. The Art. Of Darkness: The Life and Fiction of the Master of the Macabre: Stephen King. London, Hodder \& Stoughton.

Information about the author:

Didukh L. I.,

Ph.D.,

Associate Professor at the Department of Foreign Languages and Translation Studies,

Lviv State University of Life Safety 35, Kleparivska str., Lviv, 79007, Ukraine 